\title{
IMPLEMENTASI PENDIDIKAN KARAKTER DALAM PEMBELAJARAN PENDIDIKAN KEWARGANEGARAAN DI SMP BUMI KHATULISTIWA
}

\author{
$\operatorname{Moad}^{1}$, Zuldafrial ${ }^{2}$ \\ 1,2 Program Studi PPKN Fakultas Ilmu Pendidikan dan Pengetahuan Sosial IKIP PGRI Pontianak \\ Jl. Ampera Nomor 88 Pontianak-78116, Telepon (0561) 748219 Fax. (0561) 6589855 \\ Email: moad_54@yahoo.com
}

\begin{abstract}
Abstrak
Penelitian ini bertujuan untuk mengetahui implementasi nilai-nilai pendidikan karakter dalam pembelajaran pendidikan kewaranegaraan di jenjang sekolah menengah pertama (SMP). Penelitian ini merupakan penelitian dasar dengan pendekatan kualitatif dengan bentuk studi kasus. Adapun sumber data yang digunakan dalam penelitian ini adalah Informan terdiri dari kepala sekolah, guru PKn, dan siswa serta dokumen pemebelajaran terdiri dari silabus, RPP, foto pembelajaran dan penilai pembelajaran. Internalisasi nilai pendidikan karakter dalam pembelajaran pendidikan kewarganegaraan di SMP Bumi Khatulistiwa maliputi (1) Rencana pelaksanaan pembelajaran (RPP) yang dikembangkkan guru mencakup aspek sikap, pengetahuan, dan keterampilan. Karakter yang di kembangkan dalam pembelajaran meliputi: Religius, Jujur, Toleransi, Disiplin, Kerja Keras, Kreatif, Mandiri, Demokratis, Menghargai Prestasi, Bersahabat/ Komunikatif, Peduli Lingkungan, Peduli sosial, Tanggung jawab yang di kembangkan malalui Materi pembelajaran yang memuat fakta, konsep, prinsip, dan prosedur yang relevan dengan ilmu pendidikan kewaganegaraan bersumber dari buku media sosial, publikasi dan media cetak yang tersebar dalam satuan perangkat pembelajaran yang di rencanakan guru dalam pembelajaran pendidikan kewarganegaraan yang dirancang guru dalam rancangan satu semester. Motode bervariasi dengan mendepankan metode studen center dan konfensional. Pada proses pelaksanaan implementasi nilai-nilai pendidikan karakter dalam pembelajaran PKn dapat dilihat dari beberapa bagian, proses pembelajaran, Materi, Strategi atau metode pembelajaran yang digunakan, media pembelajaran yang digunakan, dan evaluasi yang digunakan. Strategi dan motode yang digunakan oleh guru PKn dalam pembelajaran yang mengimplemntasikan nilai-nilai pendidikan karakter memliputi: (1) Strategi Pembelajaran Langsung (2) Strategi Pembelajaran Interaktif (interactive instruction) (3) Strategi Pembelajaran melalui Pengalaman (4) Strategi Pembelajaran Mandiri dengan media pembelajaran bersifat audio, visual dan audiovisual. Hasil akhri dari implemtasi nilai-nilai pendidikan karakter dalam pembelajaran PKn ini output pembalajarannya tidak hanya terfokus penilaian akademis tetapi juga karakter yang di internalisasikan dalam pembelajaran PKn.
\end{abstract}

Kata Kunci: Nilai, Pendidikan Karakter, PKn, SMP

\begin{abstract}
This study aims to determine the implementation of the values of character education in the learning of citizenship education at the junior high school level. This research is a basic research with a qualitative approach in the form of case studies. The data sources used in this study were informants consisting of school principals, citizenship education teachers, and students as well as learning documents consisting of syllabi, lesson plans, learning photos and learning assessors. Internalization of the value of character education in learning citizenship education in the SMP Bumi Khatulistiwa includes: (1) The lesson plan (RPP) developed by the teacher includes aspects of attitude, knowledge, and skills. Characters that are developed in learning include: Religious, Honest, Tolerance, Discipline, Hard Work, Creative, Independent, Democratic, Respect for Achievement, Friendly/Communicative, Environmental Care, Social Care, Responsibility developed through learning materials that contain facts, concepts, principles, and procedures that are relevant to citizenship education are sourced from social media books, publications and print media that are scattered in units of learning tools planned by the teacher in citizenship education learning designed by the teacher in one semester design. The method varies by prioritizing studen center and conventional methods. In the process of implementing the implementation of character education values in citizenship education can be seen from several parts, the learning process, the material, strategies or learning methods used, the learning media used, and the evaluations used. Strategies and methods used by citizenship education teachers in learning that implements the values of character education include: (1) Direct Learning Strategies (direct instruction) (2) Interactive Learning Strategies (3) Learning Strategies through Experiences (4) Independent Learning Strategies with learning media are audio, visual and audio-visual. The final results of the implementation of the values of character education in this PKn learning output are not only focused on academic assessments but also the characters internalized in citizenship education learning.
\end{abstract}

Keyword: value, character education, citizenship education, junior high school 


\section{PENDAHULUAN}

Pendidikan kewarganegaraan merupakan suatu proses yang dilakukan lembaga sebagai pendidikan politik yang bertujuan untuk membantu peserta didik untuk menjadi warga Negara yang secara politik dan ikut membangun system politik yang demokratis. Sebagai pendidikan politik /pendidikan demokrasi, pendidikan moral dan pendidikan hukum di persekolahan. Dibandingkan dengan mata pelajaran lain, mata pelajaran PKn dan Agama memiliki posisi sebagai ujung tombak dalam pendidikan karakter. Maksudnya dalam kedua mata pelajaran tersebut pendidikan karakter harus menjadi tujuan pembelajaran. Perubahan karakter peserta didik merupakan usaha yang disengaja/direncakan (instructional effect), bukan sekedar dampak ikutan/pengiring (nurturant effect). Hal ini dapat ditunjukkan bahwa komponen PKn adalah pengetahuan, ketrampilan dan karakter kewarganegaraan. Dengan kata lain tanpa ada kebijakan pengintegrasian pendidikan karakter kedalam berbagai mata pelajaran, PKn harus mengembangkan pendidikan karakter. Lebih lebih dengan adanya kebijakan pengembangan pendidikan karakter yang terintegrasi, ini merupakan tantangan untuk menunjukan bahwa PKn sebagai ujung tombak yang tajam bukan tumpul bagi pendidikan karakter (Cholisin, 2013).

Salah satu misi yang diemban PKn adalah sebagai pendidikan karakter. Karakter mengacu pada serangkaian sikap (attitudes), perilaku (behaviors), motivasi (motivations), dan keterampilan (skills). Karakter menurut Zubaedi (2011) mencakup sikap seperti keinginan untuk melakukan hal yang terbaik, kapasitas intelektual seperti kritis dan alasan moral, perilaku seperti jujur dan bertanggung jawab, mempertahankan prinsip-prinsip moral dalam situasi penuh ketidakadilan, kecakapan interpersonal dan emosional yang memungkinkan seseorang berinteraksi secara efektif dalam berbagai keadaan, dan komitmen untuk berkontribusi dengan komunitas dan masyarakatnya. Karakter seseorang terbentuk karena kebiasaan yang dilakukan, sikap yang diambil dalam menanggapi keadaan, dan kata-kata yang diucapkan kepada orang lain. Karakter ini pada akhirnya menjadi sesuatu yang menempel pada seseorang dan sering orang yang bersangkutan tidak menyadari karakternya. Orang lain biasanya lebih mudah untuk menilai karakter seseorang.

Pendidkan karakter yang utama di kembangkan dalam pendidikan kewarganegaraan yakni mengedepankan nilai-nilai perilaku manusia yang berhubungan dengan Tuhan YME, diri sendiri, sesama manusia, lingkungan, dan kebangsaan yang terwujud dalam pikiran, sikap, perasaan, perkataan, dan perbuatan berdasarkan norma-norma agama, hukum, tatakrama, budaya, dan adat istiadat. Individu yang berkarakter baik atau unggul adalah seseorang yang berusaha melakukan hal yang terbaik terhadap Tuhan YME, dirinya, sesama, lingkungan, bangsa dan negara dengan 
mengoptimalkan potensi (pengetahuan) dirinya dan disertai dengan kesadaran, emosi, dan perasaannya.

Menurut Darmiyati Zuchdi (2011) istilah karakter yang berarti 'to mark' (menandai). Lebih difokuskan pada bagaimana upaya pengaplikasian nilai kebaikan dalam benetuk tindakan atau tingkah laku. Wynne mengatakan bahwa ada dua pengertian tentang karakter. Kesatu, ia menunjukkan bagaimana seseorang bertingkah laku apabila seseorang berperilaku tidak jujur, kejam atau rakus, tentulah orang tersebut memanifestasikan perilaku buruk. Sebaliknya apabila seseorang berperilaku jujur, suka menolong, tentulah orang tersebut memanifestasikan karakter mulia. Kedua, istilah karate erat kaitannya dengan 'personality'. Seseorang baru bias disebut 'orang berkarakter' apabila tingkahlakunya sesuai kaidah moral. Oleh karena itu peran pendidikan kewarganegaraan dalam membenruk karakter muda khususnya pada jenjang pendidikan menengah khususnya Sekolah Menengah Pertama (SMP) dapat di internalisasikan dalam proses pembelajaran melupiti kurikulum, silabus, RPP, media pembelajaran, sumber belajar dan suasana belajar. Khususnya dalam pembelajaran pendidikan kewarganegaraan internalisasi nilai-nilai pendidikan karakter dalam selruh proses pembelajaran yang selaras dengan penerapan kurikulum KTSP dan K13.

Dalam upaya pengembangan pembelajaran pada kualitas dan capaian yang maksimal khususnya dalam pendidikan kewarganegaraan guru harus memiliki beberapa kompetensi. Sesuai dengan Depdiknas (2004: 4 ): Guru PKn harus memiliki keahlian (expertise) yakni: (a) Menguasai pembelajaran materi PKn di sekolah, (b) Menguasai konsep keilmuan yang relevan dengan materi pembelajaran PKn di sekolah, (c) Menguasai strategi pembelajaran PKn di sekolah, dan (4) Kontribusi (mampu berperan) terhadap tercapainya tujuan PKn dan tujuan pendidikan nasional.

Beberapa kompetasi yang dimiliki guru dalam meninternalisasikan nilai pendidikan karakter sangat ditentukan oleh kemampuan guru dalam menguasai materi PKn, guru Menguasai konsep keilmuan yang relevan dengan materi pembelajaran PKn seperti hukum, sosiologi, antropologi, menguasai strategi pembelajaran PKn dengan strategi pembelajaran yang sesuai dengan tujuan pembelajatandan mauatan materi. Dan Kontribusi (mampu berperan) terhadap tercapainya tujuan PKn dan tujuan pendidikan nasional. Dengan demikian peran lembaga pendidikan menjadi sangat penting dalam proses pendidikan krakter khususnya pemuda.

Sekolah adalah tempat dimana karakter anak ditumbuh kembangkan dengan megedepankan norma pengambilan keputusan oleh peserta didik. Lembaga pendidikan SMP Bumi Khatulistiwa mejadi wadah bagi peserta didik dalam mengembangkan karater yang dalam proses pembelajaran terdapat beberapa niali karakter yakni serangkaian sikap (attitudes), perilaku 
(behaviors), motivasi (motivations), dan keterampilan (skills). Berdasarkan uraian dilatar belakang ini, implementasi pendidikan karakter menjadi penting.

\section{METODE}

Berdasarkan rumusan masalah, penelitian ini merupakan penelitian dasar. Menurut Sutopo (2006:135) sebelum merancang pelaksanaan penelitian, perlu dipahami bahwa terdapat dua jenis penelitian, yang dibedakan dari tujuan akhirnya. Dua penelitian tersebut meliputi penelitian dasar (basic research) dan penelitian terapan (applied research). Penelitian dasar merupakan jenis penelitian yang banyak dilakukan secara individual, terutama di lingkungan akademis. Pilihan bentuk rancangan dasarnya adalah tetap menggunakan rancangan penelitian dasar, yang dalam penelitian kualitatif berupa studi kasus (Sutopo, 2006:136). Data kualitatif yang dikumpulkan terutama berupa kata-kata, kalimat atau gambar yang memiliki arti lebih bermakna dan mampu memacu pemahaman yang lebih nyata daripada sekedar sajian angka atau frekuensi (Sutopo, 2006: 40).

Atas dasar bentuk penelitain tersebut maka penelitian ini dilakukan dengan tiga tahap: (1) Tahap Orientasi: tahap ini merupakan tahap penjajakan untuk menemukan hal-hal yang menonjol, penting, berguna untuk diteliti secara mendalam, yang akan menjadi fokus penelitian. Hal ini dipandang sebagai observasi awal untuk mengenal objek penelitian, tahap ini dirasa sangat penting supaya dalam tahap berikutnya tidak canggung untuk membaur dengan orang-orang yang terlibat di dalamnya; (2) Tahap Eksplorasi; memiliki fokus yang lebih jelas sehingga dapat mengumpulkan data yang lebih terarah dan lebih spesifik dengan melakukan observasi yang ditujukan pada hal-hal yang ada kaitanya dengan fokus penelitian. dan (3) Tahap member Check; mengecek semua kebenaran data yang disusun dalam laporan, agar penelitian memperoleh data yang benar-benar akurat dan valid. Hasil wawancara dengan informan yang terkumpul dianalisis, dituangkan dalam bentuk laporan, dinilai kebenarannya melalui pendekatan empirik (empiric).

Sumber data dalam penelitian ini terdiri dari (1) Informan yaitu seseorang atau sesuatu yang dapat memberikan informasi tentang penelitian ini. Pada penelitian ini informan awal terdiri dari Kepala Sekolah, Guru PKn, dan siswa SMP Bumi Khatulistiwa. Dan (2) dokumen pemebelajaran terdiri dari silabus, RPP, foto pembelajaran dan penilai pembelajaran.

Teknik pengumpulan data yang digunakan dalam penelitian ini adalah sebagai terdiri dari: (1) Observasi langsung yang bersifat partisipasi pasif maupun aktif dimana peneliti dapat mengamati obyek penelitian. (2) Wawancara mendalam (indepth interview) yang dilakukan lebih menyerupai suatu bentuk dialog antara peneliti dan informan, agar wawancara mendalam lebih terarah maka dipersiapkan pedoman wawancara (interview guide) dan (3) Mengkaji dokumen dan 
arsip (content analysis) Pembelajaran PKn di SMP Bumi Khatulistiwa dan mengkaji sumber data dalam pencarian data yang mendukung penelitian.

Dalam penelitian kualitatif, teknik cuplikan yang digunakan adalah teknik cuplikan yang bersifat selektif dengan menggunakan pertimbangan berdasarkan konsep teoritis yang digunakan, keingintahuan pribadi peneliti, karakteristik empirisnya, dan lain-lain. Oleh karena itu cuplikan yang akan digunakan lebih bersifat purposive sampling, atau lebih tepat disebut sebagai cuplikan dengan criterion-based selection (Goetz \& LeCompte, 1984). Dalam hal ini peneliti memilih informan yang dipandang paling tahu, sehingga kemungkinan pilihan informan dapat berkembang sesuai dengan kebutuhan dan kemantapan peneliti dalam memperoleh data.

Selanjutnya cuplikan semacam ini lebih cenderung sebagai internal sampling (Bogdan \& Biklen,1982) yang memberi kesempatan bahwa keputusan bisa diambil begitu peneliti mempunyai suatu pikiran umum yang muncul mengenai apa yang sedang dipelajari, dengan siapa akan bicara, kapan perlu melakukan observasi yang tepat (time sampling), dan juga berapa jumlah serta macam dokumen yang perlu ditelaah.

Validitas data yang dikembangkan dalam penelitian adalah trianggulasi metode. trianggulasi metode dilakukan untuk lebih memantapkan hasil pengumpulan data yang kemudian hasilnya ditarik simpulan data yang lebih kuat validitasnya. Jadi antara trianggulasi data dengan trianggulasi metode nanti diharapkan ada kesesuaian dalam perumusan analisis hasil interpretasi dan wawancara. Teknik analisis interaktif ini memiliki tiga komponen analisis yaitu reduksi data, sajian data dan penarikan kesimpulan atau verifikasi (Sutopo, 2006: 120).

\section{HASIL DAN PEMBAHASAN}

\section{Perencanaan guru dalam mengimplentasikan nilai-nilai pendidikan karakter dalam pembelajaran PKn.}

Guru PKn SMP Bumi khatulistiwa sebelum memulai pembelajaran sudah membuat Rencana Pelaksanaan Pembelajaran (RPP) yang dikembangkan berdasarkan Silabus yang telah disusun dan langsung mengarah kepada kegaiatan belajar mengajar di dalam kelas yang akan dilaksanakannya guna mencapai kompetensi dasar. Rencana pelaksanaan pembelajaran (RPP) yang dikembangkkan guru mencakup aspek sikap, pengetahuan, dan keterampilan dengan demikian pembelajaran pendidikan kewarganegaaan yang di kembangkan mengacu pada perkembangan kompetensi yang utuh dan mengembangkan seluruh aspek perkembangan pribadi siswa yang sangat diperlukan untuk menjadi pribadi yang tangguh.

Karakter yang di kembangkan dalam pembelajaran meliputi: Religius, Jujur, Toleransi, Disiplin, Kerja Keras, Kreatif, Mandiri, Demokratis, Menghargai Prestasi, Bersahabat/ 
Komunikatif, Peduli Lingkungan, Peduli sosial, Tanggung jawab yang tersebar dalam satuan perangkat pembelajatran yang direncanakan guru dalam pembelajaran pendidikan kewarganegaraan. Karakter yang di maksudkan tersebut tersebar dalam sebaran rencana pembalajaran yang dirancang guru dalam rancangan satu semester.

Materi yang direnacanakan memuat Materi pembelajaran yang memuat fakta, konsep, prinsip, dan prosedur yang relevan dengan ilmu pendidikan kewaganegaraan bersumber dari buku media sosial, publikasi dan media cetak. Sumber yang dominan di jadikan sumber ialah buku pelajaran yang menjadi sumber utama pembelajaran dan buku pengayaan yang memuat konsep, prinsip dan prosedur. Untuk lebih lengkap di lakukan pencarian sumber belajar yang lebih Up to date yakni hasil penelitian dalam bentuk artikel ilmiah, koran On line, dan koran cetak. Sumber belajar dapat berupa buku, media cetak dan elektronik, alam sekitar, atau sumber belajar lain yang relevan,

Metode pembelajaran yang di rencanakan bersifat studen senter yakni metode pembelajaran yang menitik beratkan pada pemaksimalan siswa dalam pembelajaran. metode student senter yang direncanakan untuk mewujudkan suasana belajar dan proses pembelajaran agar siswa yang lebih aktif dalam upaya pencapaian Kompetensi Dasar yang disesuaikan.

Media pembelajaran yang direncana berdasarka pada RPP yang di rencanakan guru dengan media visual audio, dan audio visual, dengan pengunaan alat bantu proses pembelajaran untuk menyampaikan materi pelajaran seperti Infokus, Spikear, dan media gambar.

Merancang RPP secara lengkap dan sistematis agar pembelajaran berlangsung secara interaktif, inspiratif, menyenangkan, menantang, memotivasi siswauntuk berpartisipasi aktif serta memberikan ruang yang cukup bagi prakarsa, kreativitas dan kemandirian sesuai dengan bakat minat dan perkembangan fisik, serta psikologis siswa (Rusman, 2013).

Peraturan Menteri Pendidikan dan Kebudayaan Nomor 22 Tahun 2016 tentang Standar Proses Pendidikan Dasar dan Menangah menyebutkan bahwa Rencana Pelaksanaan Pembelajaran (RPP) adalah rencana kegiatan pembelajaran tatap muka untuk satu pertemuan atau lebih. Setiap pendidik pada satuan pendidikan berkewajiban menyusun RPP secara lengkap dan sistematis agar pembelajaran berlangsung secara interaktif, inspiratif, menyengkan, menantang, efisien, memotivasi siswauntuk berpartisipasi aktif, serta memberikan sesuai dengan bakat, minat, dan perkembangan fisik serta psikologis siswa. RPP disusun berdasarkan Kompetensi Dasar (KD) atau subtema yang dilaksanakan kali pertemuan atau lebih. 
RPP yang disusun guru SMP Bumi Khatulistiwa telah sesuai dengan prinsip-prinsip penyusunan Rencana Pelaksanaan Pembelajaran sebagaimana dengan prinsip-prinsip RPP yang diuraikan oleh Rusman (2013) antara lain sebagai berikut :

1. Memperhatikan Perbedaan Individu Siswa

Rencana Pelaksanaan Pembelajaran disusun dengan memperhatikan perbedaan jenis kelamin, kemampuan awal, tingkat intelektual, minat, motivasi belajar, bakat, potensi, kemampuan sosial, emosi, gaya belajar, kebutuhan khusus, kecepatan belajar, latar belakang budaya, norma, nilai dan lingkungan siswa.

2. Mendorong Partisipasi Aktif Siswa

Rencana Pelaksanaan Pembelajaran disusun dengan berpusat pada siswauntuk mendorong motivasi, minat, kreativitas, inisiatif, inspirasi, kemandirian dan semangat belajar.

3. Mengembangkan Budaya Membaca dan Menulis

Rencana Pelaksanaan Pembelajaran disusun untuk mengembangkan kegemeran membaca, pemahaman beragam bacaan, dan berekspresi dalam berbagai bentuk tulisan.

4. Memberikan Umpan Balik dan Tindak Lanjut

Rencana Pelaksanaan Pembelajaran memuat rancangan program pemberian umpan balik positif, penguatan, pengayaan, dan remedi.

5. Keterkaitan dan keterpaduan

Rencana Pelaksanaan Pembelajaran disusun dengan memperhatikan keterkaitan dan keterpaduan antara standar kompetensi, kompetensi dasar, materi pembalajaran, kegiatan pembelajaran, indikator pencapaian kompetensi, penilaian dan sumber belajar dalam satu kesatuan pengalaman belajar. Rencana Pelaksanaan Pembelajaran disusun dengan mengakomodasikan pembelajaran tematik, keterpaduan lintas mata pelajaran, lintas aspek belajar dan keragaman budaya.

6. Menerapkan Teknologi Informasi dan Komunikasi

Rencana Pelaksanaan Pembelajaran disusun dengan mempertimbangkan penerapan teknologi informasi dan komunikasi secara terintegrasi, sistematis, dan efektif sesuai dengan situasi dan kondisi.

\section{Pelaksanaan guru dalam mengimplementasikan nilai-nilai pendidikan karakter dalam pembelajaran Pendidikan kewarganegaraan.}

Pada proses pelaksanaan implementasi nilai-nilai pendidikan karakter dalam pembelajaran PKn dapat dilihat dari beberapa bagian, proses pembelajaran, Materi, Strategi atau metode pembelajaran yang digunakan, media pembelajaran yang digunakan, dan evaluasi yang digunakan. 
Materi PKn yang disampaikan memuat nilai-nilai pendidikan karakter. Materi menjadi sangat penting dalam proses implementasi nilai-nilai pendidikan karakter, karena merupakan hal pokok yang akan diterima oleh siswa sebagai bahan pengetahuan. Materi pembelajaran pada hakikatnya adalah isi dari materi pelajaran yang diberikan kepada siswa sesuai dengan kurikulum yang digunakan dalam sistem pendidikan nasional. Secara umum sifat dari materi pelajaran dapat dibedakan menjadi beberapa katagori, yakni: fakta, konsep, prinsip dan keterampilan (Suryosubroto, 2009).

Materi Pembelajaran dapat dibedakan menjadi dua bagian yakni materi formal dan materi informal. Materi formal, berisi pelajaran yang terdapat dalam buku teks resmi (buku paket) di sekolah. Sedangkan materi informal, ialah bahan-bahan pelajaran yang bersumber dari lingkungan sekolah. Bahan-bahan yang bersifat informal dibutuhkan agar pembelajaran lebih relevan dan aktual (Gulo, 2008). Pengembagan materi pembelajaran harus dilakukan oleh guru, dengazn menggabung memadukan antara materi formal dan materi informal tersebut.

Upaya mengimplementasikan rencana pembelajaran yang telah disusun dalam kegiatan nyata, agar tujuan yang telah disusun dapat tercapai secara optimal, maka diperlukan suatu metode yang digunakan untuk merealisasikan strategi yang telah ditetapkan. Dengan demikian bisa terjadi satu strategi pembelajaran menggunakan beberapa metode. Oleh sebab itu, strategi berbeda dengan metode. Strategi menunjukan pada sebuah perencanaan untuk mencapai sesuatu, sedangkan metode adalah cara yang dapat digunakan untuk melaksanakan strategi (Rusman, 2013).

Strategi dan metode pembelajaran sangat berguna, baik bagi bagi guru maupun bagi siswa. Bagi guru, startegi dapat dijadikan pedoman dan acuan bertindak yang sistematis dalam pelaksanaan pembelajaran. Bagi siswa, dapat mempermudah proses belajar siswa (mempermudah dan mempercepat memahami isi pembelajaran), karena setiap strategi dan metode pembelajaran dirancang untuk mempermudah proses belajar siswa (Wena, 2012).

Dalam proses pembelajaran membutuhkan strategi dan metode pembelajaran guna mencapai tujuan pembelajaran secara efektif dan optimal. Guru sebagai kreator di dalam kelas harus lebih kreatif dalam memilih strategi dan metode pembelajaran. Pemilihan strategi dan metode pembelajaran yang tepat akan membuat suasana kelas menjadi hidup dan mampu membuat ketertarikan dan keaktifan siswameningkat. Memilih strategi dan metode yang tepat adalah tugas guru untuk mengelola pembelajaran menjadi efektif dan menarik. Mudasir (2011:66) mengatakan bahwa Peran seorang guru pada pengelolaan kelas sangat penting khususnya dalam menciptakan suasana pembelajran yang menarik. Itu karena secara prinsip, guru memegang dua tugas sekaligus 
masalah pokok, yakni pengajaran dan pengelolaan kelas. Pengajaran terkait usaha membantu siswauntuk mencapai tujuan pembelajaran. Sedangkan pengelolaan berkaitan dengan usaha untuk menciptakan dan mempertahankan kondisi sehingga proses pembelajaraan dapat berjalan secara efektif dan efisien demi tercapainya tujuan pembelajaran.

Ada beberapa strategi dan motode yang digunakan oleh guru PKnn SMP Bumi Khatulistiwa dalam pembelajaran yang mengimplemntasikan nilai-nilai pendidikan karakter sehingga dapat membangkitkan rasa ingin tahu,sikap kritis, dan kreativitas siswa.

1. Strategi Pembelajaran Langsung (direct instruction)

a. Strategi ini berpusat pada guru dan paling sering digunakan terutama dalam pembelajaran PKn. beberapa metode yang termasuk dalam strategi ini misalnya ceramah, pertanyaan didaktik, pengajaran eksplisit praktek dan latihan, serta demonstrasi.

b. Strategi ini cocok untuk pembelajaran PKn berbasis character building karena cukup efektif digunakan untuk memperluas informasi atau mengembangkan keterampilan langkah demi langkah.

2. Strategi Pembelajaran Interaktif (interactive instruction)

a. Strategi ini merujuk kepada bentuk diskusi dan saling berbagi di antra siswa. Dalam pembelajaran PKn strategi ini mampu merangsa cara berfikir kritis pesera didik terhadap materi PKn yang dibahas.

b. Strategi ini dikembangkan dalam rentang pengelompokan dan metode-metode interaktif. Di dalamnya terdapat bentuk-bentuk diskusi kelas, diskusi kelompok kecil atau pengerjaan tugas berkelompok, dan kerja sama siswa secara berpasangan.

3. Strategi Pembelajaran melalui Pengalaman (experiential learning)

a. Strategi belajar melalui pengalaman menggunakan bentuk sekuens induktif, berpusat pada siswa dan berorientasi pada aktivitas.

b. Penekanan dalam strategi ini belajar melalui pengalaman adalah proses belajar dan bukan hasil belajar.

c. Guru PKn dapat menggunakan strategi ini baik di dalam kelas maupun di luar kelas. Contohnya, di dalam kelas dengan menggunakan metode simuluasi, sedangkan di luar kelas dapat dikembangkan metode observasi melalui karya wisata untuk memperoleh gambaran umum yang terjadi di lingkungan sekitar siswa.

4. Strategi Pembelajaran Mandiri 
a. Pembelajaran PKn dengan menggunakan strategi pembelajaran mandiri bertujuan untuk membangun inisiatif individu, kemandirian, dan peningkatan diri.

b. Fokus dari strategi ini adalah pada perencanaan belajar mandiri juga bisa dilakukan dengan teman atau sebagai bagian dari kelompok kecil.

Media pembelajaran memiliki makna alat yang digunakan sebagai penyampai pesan dalam hal pembelajaran yang dimaksud adalah materi ajar kepada siswasehingga siswadapat dengan mudah menerimanya. Menurut Gerlach dan Ely (Arsyad, 2011), mengatakan media apabila dipahami secara garis besar adalah manusia, materi, atau kejadian yang membangun kondisi yang membuat siswa memperoleh pengetahuan, keterampilan, atau sikap”. Dalam pengertian ini, guru, buku teks dan lingkungan sekolah adalah media. Media pembelajaran merupakan alat dan bahan kegiatan yang digunakan dalam pembelajaran yang dapat merangsang siswa untuk belajar.

Dalam proses pembelajaran, media memiliki fungsi sebagai pembawa informasi dari sumber (guru) menuju penerima (siswa). Menurut Asyhar (2012) dari segi psikologi, media pembelajaran memiliki beberapa fungsi seperti: (1) Fungsi atensi yaitu, Media pembelajaran dapat menghambil perhatian (attention catcher) siswaterhadap materi yang dibahas, (2) Fungsi afektif, yaitu Media pembelajaran dapat meningkatkan partisipasi (keaktifan) siswadalam seluruh proses pembelajaran yang antara lain diungkapkan dalam bentuk reaksi siswaterhadap pembelajaran yang sedang diikutinya. Media pembelajaran mengaktifkan respon siswa, memberi umpan balik dengan segera (feedback soon), (3) Fungsi kognitif, yakni Fungsi kognitif dari suatu media pembelajaran dimaksudkan bahwa media tersebut memberikan pengetahuan dan pemahaman baru kepada siswatentang sesuatu, (4) Fungsi psikomotorik yakni Psikomotorik berhubungan dengan keterampilan yang bersifat fisik atau tampilan pada seseorang, (5) Fungsi imajinatif, yakni Media merupakan salah satu alternatif strategi yang dapat difungsikan untuk membangkitkan dan mengembangkan daya imajinasi siswa, Dan (6) Fungsi Motivasi, yakni Media pembelajaran dapat membangkitkan motivasi belajar siswa, sebab penggunaan media pembelajaran menjadi lebih menarik dan memusatkan perhatian siswa.

Menurut Susanto (2014) media pembelajaran secara garis besar terbagi menjadi audio, visual dan audio-visual. Media audio dapat berupa rekaman, misalnya rekaman pembacaan teks proklamasi. Media visual dapat berupa media cetak dan elektronik, termasuk dalam media cetak adalah arsip atau dokumen, dan dokumen berita seperti surat kabar. Sedangkan media elektronik visual dapat berupa gambar bergerak tanpa suara. Sedangkan media audio-visual berupa video dan film dokumenter. 
Secara teoritis evaluasi adalah suatu usaha sistematik dan sistematik untuk mengumpulkan, menyusun, dan mengolah data, fakta, dan informasi dengan tujuan menyimpulkan nilai, makna, kegunaan, prestasi dari suatu program, dan hasil kesimpulan tersebut dapat digunakan dalam rangka pengambilan keputusan, perencanaan, maupun perbaikan dari suatu program. Ada tiga konsep yang sering dipakai dalam melakukan evaluasi, yakni: tes, pengukuran dan penilaian (Aman, 2011). Kemudian Sudijono (2012) menyebutkan evaluasi memiliki tiga macam fungsi pokok sebagai suatu tindakan atau proses yaitu: (1) mengukur kemajuan, (2) menunjang penyusunan rencana, dan (3) memperbaiki atau melakukan pemnyempurnaan kembali.

Evaluasi harus dilaksanakan dengan terencana sejak awal bahakan sebelum proses pembalajaran belum dilaksanakan. Sanjaya (2011), dalam perencanaan dan desain instruksional atau pembelajaran, rancangan evaluasi merupakan hal yang sangat penting untuk dikembangkan. Hal ini disebabkan melalui evaluasi yang tepat, kita dapat menentukan efektivitas program dan keberhasilan siswamelaksanakan kegiatan pembalajaran, sehingga informasi dari kegiatan evaluasi seorang yang merencanakan pembelajaran dapat mengambil keputusan apakah program pembelajaran yang dirancangnya perlu diperbaiki atau tidak, bagian-bagian mana yang dianggap memiliki kelemahan sehingga perlu diperbaiki.

Untuk melihat hasil dari pembelajaran tentu harus menggunakan evaluasi. Dalam implemantasi nilai-nilai PKn ini evaluasi adalah hal yang mutlak mesti dilakukan. Pelaksanaan evaluasinya tidak hanya melihat hasil belajar yang biasanya berupa angka-angka saja, namun untuk melihat hasil dari pembentukan karakter ini juga harus mencapai pada penilaian perubahan sikap, apakah terdapat perubahan prilaku baik yang signifikan atau tidak.

Hasil akhri dari implemtasi nilai-nilai pendidikan karakter dalam pembelajaran PKn ini output pembalajarannya tidak hanya terfokus penilaian akademis tetapi juga karakter yang di internalisasikan dalam pembelajaran PKn di kelas. Beberapa nilai pendidikan karakter yang dikembangkan dalam pembelajaran pendidikan kewarganegaraan yakni:

1) Sikap dan perilaku yang patuh dalam melaksanakan ajaran agama yang dianutnya, toleran terhadap pelaksanaan ibadah agama lain, dan hidup rukun dengan pemeluk agama lain.

2) Sikap dan tindakan yang menghargai perbedaan agama, suku, etnis, pendapat, sikap, dan tindakan orang lain yang berbeda dari dirinya.

3) Tindakan yang menunjukkan perilaku tertib dan patuh pada berbagai ketentuan dan peraturan.

4) Perilaku yang menunjukkan upaya sungguh-sungguh dalam mengatasi berbagai hambatan belajar dan tugas, serta menyelesaikan tugas dengan sebaik-baiknya. 
5) Berpikir dan melakukan sesuatu untuk menghasilkan cara atau hasil baru dari sesuatu yang telah dimiliki. Dapat dimanai sebagai jiwa yang kreatif.

6) Sikap dan perilaku yang tidak mudah tergantung pada orang lain dalam menyelesaikan tugas-tugas dapat dimainai sebagai jiwa yang berperinsip.

7) menjunjung tinggi persamaan hak dan kewajiban yang tercermian dalam Cara berpikir, bersikap, dan bertindak yang menilai sama hak dan kewajiban dirinya dan orang lain.

8) Cara berpikir, bertindak, dan berwawasan yang menempatkan kepentingan bangsa dan negara di atas kepentingan diri dan kelompoknya.

9) membiasakan buadaya literasi yakni Kebiasaan menyediakan waktu untuk membaca berbagai bacaan yang memberikan kebajikan bagi dirinya.

10) Sikap dan tindakan yang selalu berupaya mencegah kerusakan pada lingkungan alam di sekitarnya, dan mengembangkan upaya-upaya untuk memperbaiki kerusakan alam yang sudah terjadi.

11) Sikap dan tindakan yang selalu ingin memberi bantuan pada orang lain dan masyarakat yang membutuhkan.

12) Sikap dan perilaku seseorang untuk melaksanakan tugas dan kewajibannya, yang seharusnya dia lakukan, terhadap diri sendiri, masyarakat, dan lingkungan (alam, sosial, dan budaya), negara, dan Tuhan YME. Penilaian otentik memiliki relevansi kuat terhadap pendekatan ilmiah (scientific approach) dalam pembelajaran sesuai dengan tuntutan kurikulum 2013.

Penilaian otentik mampu menggambarkan peningkatan hasil belajar siswa, baik dalam rangka mengamati, menanya, mengumpulkan informasi, menalar/mengasosiasi, atau mengomunikasikan. Penilaian otentik cenderung fokus pada tugas-tugas kompleks atau kontekstual, memungkinkan siswa untuk menunjukkan kompetensi yang meliputi sikap, pengetahuan, dan keterampilan (Kementerian Pendidikan dan Kebudayaan, 2016).

\section{SIMPULAN}

Internalisasi nilai pendidikan karakter dalam pembelajaran pendidikan kewarganegaraan di SMP Bumi Khatulistiwa maliputi (1) Rencana pelaksanaan pembelajaran (RPP) yang dikembangkkan guru mencakup aspek sikap, pengetahuan, dan keterampilan. Karakter yang di kembangkan dalam pembelajaran meliputi: Religius, Jujur, Toleransi, Disiplin, Kerja Keras, Kreatif, Mandiri, Demokratis, Menghargai Prestasi, Bersahabat/ Komunikatif, Peduli Lingkungan, Peduli sosial, Tanggung jawab yang tersebar dalam satuan perangkat pembelajatran yang di rencanakan guru dalam pembelajaran pendidikan kewarganegaraan yang dirancang guru dalam 
rancangan satu semester. Materi yang direnacanakan memuat Materi pembelajaran yang memuat fakta, konsep, prinsip, dan prosedur yang relevan dengan ilmu pendidikan kewaganegaraan bersumber dari buku media sosial, publikasi dan media cetak. Motode bervariasi dengan mendepankan metode studen center dan konfensional. (2) Pada proses pelaksanaan implementasi nilai-nilai pendidikan karakter dalam pembelajaran PKn dapat dilihat dari beberapa bagian, proses pembelajaran, Materi, Strategi atau metode pembelajaran yang digunakan, media pembelajaran yang digunakan, dan evaluasi yang digunakan. Materi PKn yang disampaikan memuat nilai-nilai pendidikan karakteryakni materi yang menjelaskan fakta, konsep, prinsip dan keterampilan. Strategi dan motode yang digunakan oleh guru PKn SMP Bumi Khatulistiwa dalam pembelajaran yang mengimplemntasikan nilai-nilai pendidikan karakter memliupti: (1) Strategi Pembelajaran Langsung (direct instruction) seperti latihan dan demonstrasi. (2) Strategi Pembelajaran Interaktif (interactive instruction) seperti diskusi kelas, diskusi kelompok kecil atau pengerjaan tugas berkelompok, dan kerja sama siswa secara berpasangan, (3) Strategi Pembelajaran melalui Pengalaman (experiential learning) berpusat pada siswa dan berorientasi pada aktivitas seperti menggunakan metode simuluasi. Dan (4) Strategi Pembelajaran Mandiri yang di tujukan untuk membangun inisiatif individu, kemandirian, dan peningkatan diri. Media pembelajaran secara garis besar terbagi menjadi audio, visual dan audio-visual. Media audio dapat berupa rekaman, misalnya rekaman pembacaan teks proklamasi. Media visual dapat berupa media cetak dan elektronik, termasuk dalam media cetak adalah arsip atau dokumen, dan dokumen berita seperti surat kabar. Sedangkan media elektronik visual dapat berupa gambar bergerak tanpa suara. Sedangkan media audio-visual berupa video dan film dokumenter.Hasil akhri dari implemtasi nilai-nilai pendidikan karakter dalam pembelajaran PKn ini output pembalajarannya tidak hanya terfokus penilaian akademis tetapi juga karakter yang di internalisasikan dalam pembelajaran PKn di kelas.

\section{DAFTAR PUSTAKA}

Ades, Sanjaya. 2011. Model-model Pembelajaran. Bumi Aksara. Jakarta. Aman. 2011. Model Evaluasi Pembelajaran Sejarah. Yogjakarta: Ombak

Anas, Sudijono 2012. Pengantar Evaluasi Pendidikan. Jakarta: Raja Grafindo. Persada,

Bogdan, C.R \& Biklen 1982. Qualitative research for education: An introduction to theory and methods. Boston: Ally and Bacon Inc.

Cholisin. 2013. Ilmu Kewarganegaraan (Civics). Yogyakarta: Penerbit Ombak.

Darmiyati Zuchdi. (2011). Pendidikan Karakter dalam Perspektif Teori dan. Praktik. Yogyakarta: UNY Press. 
Depdiknas. (2004). Kerangka Dasar Kurikulum 2004, Jakarta. Departemen Pendidikan Nasional. (2006). Kurikulum 2006. Jakarta Media

Goetz, J.P. \& Le Compte, M.D. 1984. Ethnography and Qualitative Design in. Educational Research. San Diego: Academic Press. Yogyakarta:Pustaka Pelajar.

Gulo,W. 2008. Strategi Belajar Mengajar. Jakarta: PT. Grasindo.

Kurniawan, Syamsul. 2013. Pendidikan Karakter: Konsepsi dan Implementasinya Pada Lingkungan Keluarga, Sekolah, Perguruan Tinggi dan Masyarakat. Yogyakarta: Arruzz.

Kurniawan, Syamsul. 2017. Pendidikan Karakter di Sekolah: Revitalisasi Peran Sekolah dalam Menyiapkan Generasi Bangsa yang Berkarakter. Yogyakarta: Samudera Biru.

Made, Wena. (2011). Strategi Pembelajaran Inovatif Kontemporer: Suatu Tinjauan. Konseptual Operasional. Jakarta: PT. Bumi Aksara.

Mudasir. 2011. Manajemen Kelas. Zanafa Publishing Dan Fakultas Tarbiyah Dan Keguruan Uin Suska Riau. Riau.

Permendikbud. (2016) Peraturan Menteri Pendidikan dan Kebudayaan Republik Indonesia No. 22 Tahun 2016 Tentang Standar Proses Pendidikan Dasar dan Menengah

rsyad, Azhar. 2011. Media Pembelajaran. Jakarta: PT Raja Grafindo Persada.

Rusman. 2013. Model-Model Pembelajaran. Jakarta: Raja Grafindo Persada

Suryosubroto. (2009). Proses Belajar Mengajar di Sekolah. Jakarta: PT Rineka. Cipta

Sutopo. H.B. 2006. Metode Penelitian Kualitatif Dasar Teori dan Penerapanya Dalam Penelitian. Surakarta:UNS Press.

Zubaedi (2011), pendidikan Karakter: Konsep Dan Aplikasinya Dalam Lembaga Pendidikan, Jakarta: kencana 